\title{
Práticas curriculares em (per) curso: experiências iniciais de uma Licenciatura em Dança
}

Candice Didonet. Jéssica Jesse Félix Severo. Universidade Federal da Paraíba. candicedidonet@gmail.com; jessicajfsevero@gmail.com

O presente texto teve como impulso inicial o desejo de compartilhar e trocar experiências vindas de uma professora e uma estudante do curso de Licenciatura da Universidade Federal da Paraíba. A fim de refletir sobre inquietações oriundas de um curso recém-inaugurado, as reflexões giram em torno do problema de como ensinar a dança de uma maneira em que a investigação seja a principal conduta, onde processos criativos estejam presentes em todas as etapas. Torna-se importante salientar maneiras de fazer dança que não estejam pautadas na reprodução de modelos pré-estabelecidos e que seja criativo, no sentido de ser transformador e de possibilitar novidades. A busca por traduzir inquietações em formato de texto leva à observação de metodologias e epistemologias de ensino e aprendizagem no campo das Artes Cênicas com reflexões sobre ensinar e aprender dança de formas investigativas. Assim, há apontamentos para como processos de ensino- aprendizagem geram possibilidades abertas de relação com o mundo junto das questões pessoais dos estudantes.

Os processos de ensino-aprendizagem baseados em procedimentos investigativos podem ser abordados através de dois processos: educativo e artístico. No processo educacional, na relação professor-aluno, abrange as questões envolventes ao ensinar e ao aprender. A operacionalização do processo artístico, por exemplo, é um dos modos como se estabelece o conhecimento em dança.

Segundo Kastrup (2010) para abordar a investigação como modo de conduta de ensino é preciso trazer a aprendizagem inventiva no compartilhamento de problemas, na invenção de problemas e não na sua solução. A aprendizagem inventiva pode ser vivenciada no cotidiano, e na prática artística se encontra um dos modos como ela se processa. Assim, as experiências educativas e artísticas implicam não apenas na aquisição de habilidades, mas na modificação da sensibilidade, da percepção do mundo, da existência, tratando-se, portanto, de aprendizagens que possibilitam a "invenção recíproca e indissociável de si e do mundo" (KASTRUP, 2005, p.1277).

Com esta premissa, podemos dizer que os processos de ensino-aprendizagem em dança articulam epistemologias criativas e inventivas que atenuam a separação daquilo que se aprende com, e, como se aprende, com, e, como agimos em relação ao aprender. A conexão 
entre o que se aprende e o que se vive pode atenuar a separação entre teoria e prática, educação e criação nos processos de ensino e aprendizagem em dança.

Aprender investigando: a educação em dança é criação compartilhada, dissertação de TRIDAPALLI (2008) propõe a supressão entre prática e teoria, criação e educação. Dançar move e é uma ação cognitiva do corpo, por isto, não existe um modo único e universal do corpo aprender dança. Ao levar em conta a educação como um processo de criação, as experiências de investigação podem ser concomitantes aos modos de aprendizado e aos contextos que geram. Corroborando com o pensamento de Kastrup (2010), a autora aproxima distâncias entre educação e criação, elucidando que o ato de aprender dança é um processo de tentativas, adaptações e descobertas problematizadas a fim de solucionar questões, conceitos e ações implicados no ensino-aprendizagem investigativo.

A lógica de funcionamento educacional pautada na ideia de que o professor é aquele que ensina e o aluno aquele que aprende precisa ser repensada com ações que borrem modos de conduta em aula. O que se ensina e o que se aprende são como se ensina e o como se aprende. O aprender em dança é determinado pela natureza instável e incerta do próprio corpo. Um dos modos de sensibilização para estas questões está justamente no fato de que o corpo, como especificidade humana, conecta e elabora aspectos educacionais indissociáveis às experiências da própria vida.

\section{REFERÊNCIAS}

DIDONET, Candice; LARANJEIRA, Carolina Dias. Investigar para aprender: leituras de um processo de formação em curso. Anais do III Congresso Nacional de Pesquisadores em Dança. 2014, p.1-17.

KASTRUP, Virgínia. Políticas cognitivas na formação do professor e o devir-mestre. Educação e Sociedade, Campinas, vol. 26, n. 93, Set./Dez. 2005, p. 1273-1288.

TRIDAPALLI, Gladistoni dos Santos. Aprender investigando: a educação em dança é criação compartilhada. Dissertação de Mestrado. Programa de Pós Graduação em Dança, Universidade Federal da Bahia, 2008. 